\title{
Experimental and Numerical Assessment of Masonry Infill on Seismic Performance of RC Frame Structure
}

\author{
Syed Azmat Ali Shah ${ }^{1 *}$, Asfandyar Ahmed ${ }^{2}$, Khan Shahzada ${ }^{3}$, Syed Muhammad Ali ${ }^{4}$, Akhtar Naeem Khan ${ }^{5}$ \\ and Akhter Gul ${ }^{6}$
}

${ }^{1}$ Centre for Disaster Preparedness and Management, University of Peshawar, Khyber Pakbtunkhwa, Pakistan; ${ }^{2}$ City University of Science and Information Technology Peshawar, Khyber Pakbtunkhwa, Pakistan; ${ }^{3}$ University of Engineering and Technology Peshawar, Khyber Pakbtunkhwa, Pakistan; 'Earthquake Engineering Center, University of Engineering and Technology Peshawar, Khyber Pakhtunkhwa, Pakistan; ${ }^{5}$ Civil, Agricultural and Mining Engineering, University of Engineering and Technology Peshawar Khyber Pakbtunkbwa, Pakistan; ${ }^{6}$ Department of Civil Engineering UET Campus-III Bannu, Khyber Pakbtunkhwa, Pakistan.

Abstract: The behavior of solid brick masonry is presented under the application of lateral loads. Two frames
made of reinforced concrete, bare frame and masonry infilled frame, were subjected to displacement controlled
lateral loading. Experimental tests and numerical modeling were performed, and the results compared show
a good relationship. The analysis results match very well with the experimental observations. For numerical
modeling of the infill wall, a modified micro-modelling approach is selected where the head and bed joints
are lumped into the bricks and an interface model was defined between these bricks representing the behavior
of the mortar joint. Appropriate material models and damage criteria are employed for each mode of failure.
A parametric study was then performed to assess the influence of different material properties on the lateral
load capacity of the RC frame infilled with masonry. It was demonstrated that for the same gravity load level
the enhancement of brick unit properties enhances the total capacity of the RC frame with infill. Similarly,
by increasing the gravity load on the structure with the same brick unit properties, the lateral load capacity
increases considerably.
Received: May 02, 2021; Accepted: June 24, 2021; Published: June 30, 2021
"Correspondence: Syed Azmat Ali Shah, Centre for Disaster Preparedness and Management, University of Peshawar, Khyber Pakhtunkhwa,
Pakistan; Email: engrazmatalishah@uop.edu.pk
Citation: Shah, SAA, A. Ahmed, K. Shahzada, S.M. Ali, A.N. Khan and A. Gul. 2021. Experimental and numerical assessment of masonry infill
on seismic performance of RC frame structure. Journal of Engineering and Applied Sciences, 40(1): 24-36.
DOI: https://dx.doi.org/10.17582/journal.jeas/40.1.24.36
Keywords: Experimental testing, Numerical modeling, Infill, Brick masonry, RC frame, Simplified micro-modeling

\section{Introduction}

$\mathrm{U}$ nreinforced masonry (URM) panels usually opt as infills/partition walls in reinforced concrete (RC) and steel frame structures. These walls have serious consequences not only for the safety of life but also for the ease of maintenance of buildings (Shing et al., 2009). Sometimes, URM filling walls, when typically used as partitions, can adversely affect the use of the structure. These structural units are very common in some countries prone to earthquakes like the United States, Turkey, Italy, China and Mexico (Change-Hai, 2014). The response of RC infilled frames, observed in previous earthquakes, is diverse, ranging from acceptable to mediocre (Rosenblueth et al., 1986). This research work focused on the role of the presence of infill brick masonry wall panel in reinforced concrete framing structures and their 
quantitative analysis.

When designing a building, infills are considered nonstructural elements. However, if in this case there are no separation gaps between the frame and the filling, they merge with the frame around it (Stavridis and Shing, 2010). This interaction can be advantageous in the case where it increases the strength and stiffness of the building. Both strength and ductility are factors involved in the seismic performance of a structure and an increase in resistance are likely to increase performance (Korkmaz et al., 2010). On the contrary, a disadvantage of the framework and filling interaction is the uncertainty of the response due to large uncertainties in the filling properties (Fiore et al., 2014). A range of damage patterns is possible for infill frames depending on the comparative stiffness and strength of the infill and adjacent RC frame (Mehrabi et al., 1994). The infill walls of the URM modify the dynamic response of the frame regarding the stiffness, natural frequency and damping (Kauffman and Memari, 2014).

The formation of soft tales is also common for such units. When significant damage to an infill panel occurs due to large seismic loads, the risk of falling debris may also be observed (Kyriakides and Billington, 2008). URM infill walls are usually made of fragile materials that quickly lose capacity. The mutual effect of fragility and high rigidity has a negative influence on the lateral load response of these frames (Hahemi and Mosalam, 2006).

The ultimate strength of a filled frame is not only the sum of the ultimate strengths of the infill panel and frame (Bertero and Brokken, 1983) but also depends on the relationships between the two. These units change their mechanisms of load resistance and damage patterns. For low drift levels, a filled chassis system acts as a monolithic composite wall, but as the drift increases, the filling may somewhat detach from the surrounding frame (Koutromanos et al., 2011). In this case, the lateral resistance is mainly provided by a diagonal compression mechanism. In this mechanism, the compressive stresses generate between the infill panel and $\mathrm{RC}$ frame. The location of this mechanism is at two diagonally opposite angles in the locality of the beam/column joints. This mechanism led several researchers to use an equivalent diagonal bar to describe the effect of filling, initially proposed by Polyakov (Polyakov, 1960).
The mechanical behavior of masonry is intricate and its characterization by laboratory tests is among the important tools offered to researchers to comprehend it. Nevertheless, laboratory masonry tests require costly and time consuming resources, as test specimens, costly and specific measuring equipment, and the large scale dispersion of properties. Material and geometric properties of masonry usually require a substantial number of samples to obtain characteristic results.

There are fascinating studies regarding the understanding of the damage pattern of masonry under axial load (Andreaus and Ceradini, 1992) and numerical modeling of masonry by finite element method (Page, 1978) to understand the behavior subjected to monotonic lateral loads (Andreaus et al., 1985a) and reverse cyclic loads (Andreaus et al., 1985b). Other studies have also been carried out on the assessment of masonry columns/piers subjected to cyclic loading (Andreaus et al.,1988a, b). The study of axially loaded masonry (Andreaus et al., 1995a, b), monotonically loaded masonry (Andreaus et al., 1995c) and masonry under seismic load (Andreaus et al., 1995a) are prominent. These approaches depend on adopting the advanced modeling procedures as well as on data acquired from simple tests carried out on the materials employed for masonry units and mortar joints. Nevertheless, the key purpose of these studies is the corroboration of proposed numerical models.

In recent years, a great number of structural models have been proposed regarding the response of structural concrete and masonry, the analytical modeling is based on: plasticity (Chen, 1975; Kang et al., 2000; Grassl et al., 2001; Thabet and Haldane, 2001), viscoplasticity (Cela, 1998; Gomes and Awruch, 2001; Barpi, 2004) damage mechanics (Cervera et al., 1996; Hatzigeorgiou et al., 2001), or a mixture of these models (Fardis et al., 1983; Chen and Buyukozturk, 1985; Yang et al., 1985; Dube et al., 1996; Faria et al., 1998). The subsequent formulations generally include numeral parameters whose assessment is essential to obtain a close association between the behavior prophesied by the model and its experimentally obtained results.

Most of these relationships are uniaxial stress-strain model (Pauw, 1960; Popovics, 1973) that are further widespread with the assumption of orthotropic or 
non-isotropic material to be used to describe the non-linear response under biaxial (Liu, 1971; Liu et al., 1972) or triaxial (Buyukozturk and Sareef, 1985; Balan et al., 1997, 2000) state of stress. Instead of developing models using simple stress-strain relation coupled to triaxial data, it is likely to propose material models by simply investigating the results acquired from triaxial tests.

Masonry has distinctive directional properties, because of the presence of mortar joints which are potential planes of weakness. Contingent to the positioning of the joints concerning applied load, damage can occur only in these joints (sliding) or concurrently in both the joints and units. According to FEMA 356, there are four main damage modes for masonry walls or masonry pillars: The diagonal tension of the box, crushing of the toes, sliding of the bed and tilting. Massive masonry panels usually fail in peak crushing modes/wedge or sliding shear failure. Therefore, the ductility of the infilled RC frames appears to be contingent on the failure mode of the infill masonry (Tasnimi and Mohebkhah, 2011).

The large quantity of manipulating aspects, for example, the size and anisotropy/orthotropy of the units, the width of the joints and the laying of the joints, the material properties and the quality of manufacture make the modeling of masonry exceptionally tough. The various numerical techniques could be adopted for masonry models (Lourenco, 2002; Asteris and Tzamtzis, 2003a, b):

- Masonry as single-phase material (MacroModelling)

- Masonry as double- phase material (Modified Micro-Modeling or Meso-Modeling)

- Masonry as triple-phase material (Detailed Micro-Modeling).

A typical large-scale RC frame was chosen from present building practices and tested under lateral loading conditions in the laboratory. Two of these types were constructed, one without infill and with masonry infill. The numerous parameters of the units were found in the laboratory, which is presented in Table 1. These tests were used for the selection of infill materials. Later, these tests were used to select the appropriate constitutive models for "Brick and mortar" in the Numerical modeling studies. The key influence of this work is to study the lateral load behavior of RC frame elements with and without masonry infill and to demonstrate the use of computer simulations to predict masonry behavior (i.e. to conduct the parametric study with different mechanical properties).

Table 1: Details of instrument layout.

\begin{tabular}{|c|c|c|c|}
\hline S. No & Instrument (Capacity) & Location & Remarks \\
\hline 1. & Load cell (500 kN, 50 ton) & Horizontally & To measure Horizontal load \\
\hline 2. & String pot (500 mm, 19.68 in) & $\begin{array}{l}\text { Beam center } \\
\text { main gauge }\end{array}$ & To measure Horizontal displacement \\
\hline 3. & LVDT (50 mm, 1.97 in) & $\mathrm{R}-\mathrm{D}$ & To measure displacement at right, diagonal of the infilled wall \\
\hline 4. & LVDT (50 mm, 1.97 in) & $\mathrm{L}-\mathrm{D}$ & To measure displacement at left, diagonal of the infilled wall \\
\hline 5. & LVDT (50 mm, 1.97 in) & CRRB & To measure displacement at bottom, right side of the right column \\
\hline 6. & LVDT (50 mm, 1.97 in) & CLLB & To measure displacement at bottom, left side of the left column \\
\hline 7. & LVDT (50 mm, 1.97 in) & CRLB & To measure displacement at bottom, right side of the left column \\
\hline 8. & LVDT (50 mm, 1.97 in) & CLRB & To measure displacement at bottom, left side of the right column \\
\hline 9. & Dial gauge (20 mm, 0.79 in) & CRRT & To measure displacement at top, right side of the right column \\
\hline 10. & Dial gauge (20 mm, 0.79 in) & CLLT & To measure displacement at top, left side of the left column \\
\hline 11. & Dial gauge (20 mm, 0.79 in) & CRLT & To measure displacement at top, right side of the left column \\
\hline 12. & Dial gauge (20 mm, 0.79 in) & CLRT & To measure displacement at top, left side of the right column \\
\hline 13. & Dial gauge (10 mm, $0.39 \mathrm{in})$ & BRT & To measure displacement at top, right side of beam \\
\hline 14. & Dial gauge (10 mm, 0.39 in) & BLT & To measure displacement at top, left side of beam \\
\hline 15. & Dial gauge (10 mm, 0.39 in) & $\mathrm{BRB}$ & To measure displacement at bottom, right side of beam \\
\hline 16. & Dial gauge (10 mm, 0.39 in) & $\mathrm{BLB}$ & To measure displacement at bottom, left side of beam \\
\hline 17. & LVDT (50 mm, 1.97 in) & FLC & To measure base slip \\
\hline 18. & Load Cell (250 kN, 25 ton) & Vertical & To measure Vertical load \\
\hline
\end{tabular}

June 2021 | Volume 40 | Issue 1 | Page 26 


\section{Materials and Methods}

Description of RC frame with and without infill wall Two single bay, single-story and full-scaled reinforced concrete (RC) frames were constructed in the experimental phase of this research. In which one was bare frame and the other was infilled with brick masonry as shown the Figure 1. The frame was designed for Seismic Zone 3 according to the Building Code of Pakistan Seismic Provision (BCP SP-2007). The structural detailing of the frame is shown in Figure 2. The frame was designed as a bare frame neglecting infilled wall using finite element software, as it is conventional design practice in Pakistan. The frames were constructed according to local constructional practices in Pakistan.
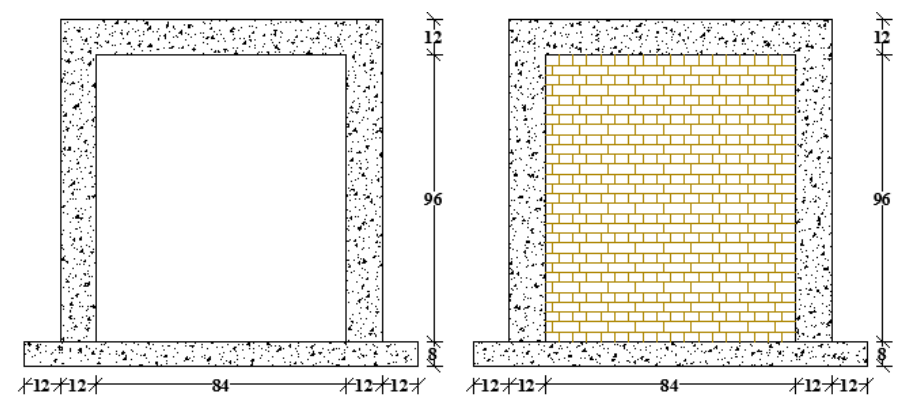

Figure 1: Schematic diagram of Bare frame and Inflled frame (dimensions in inches).

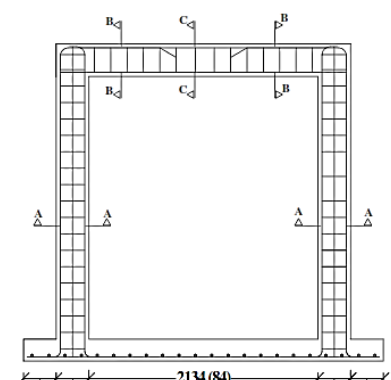

$\left.\int_{305(12)}^{x}\right|_{305(12)} ^{X}$ FRAME DETAILS ${ }^{2134(84)-\left.{ }_{305(12)}^{X}\right|_{305} ^{X}(12)}$
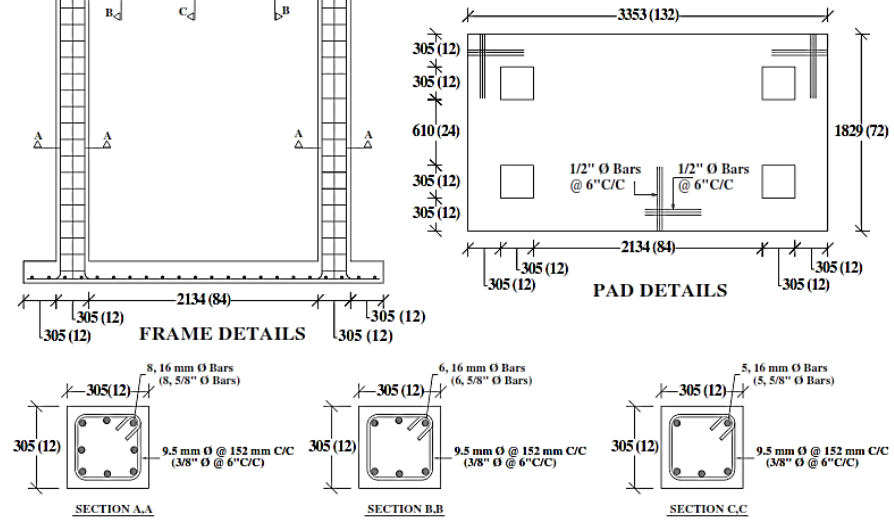

Figure 2: Structural detailing of Frame and Pad dimensions in $m m$ (inch).

\section{Test setup and instrumentation}

To depict the slab load on frame, an arrangement was made to induce constant axial load on frame through an actuator mounted over frame beam. Point load from the vertical actuator was uniformly distributed on the frame through a girder mounted on top frame beam. A second actuator was used to induce lateral displacement as shown in Figure 3.

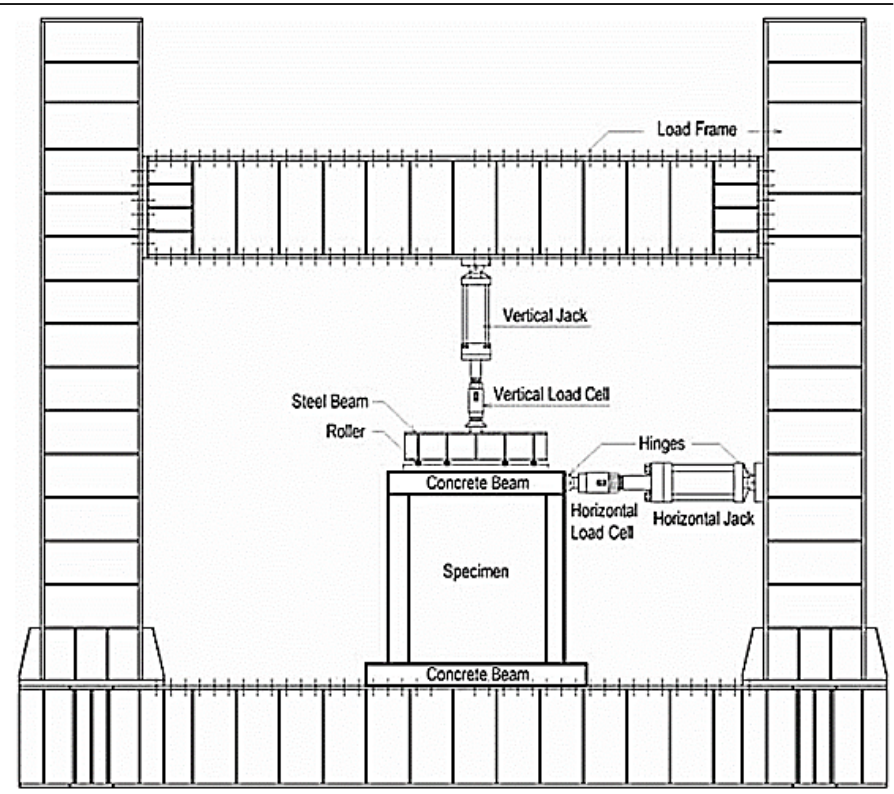

Figure 3: Schematic diagram of the test setup.
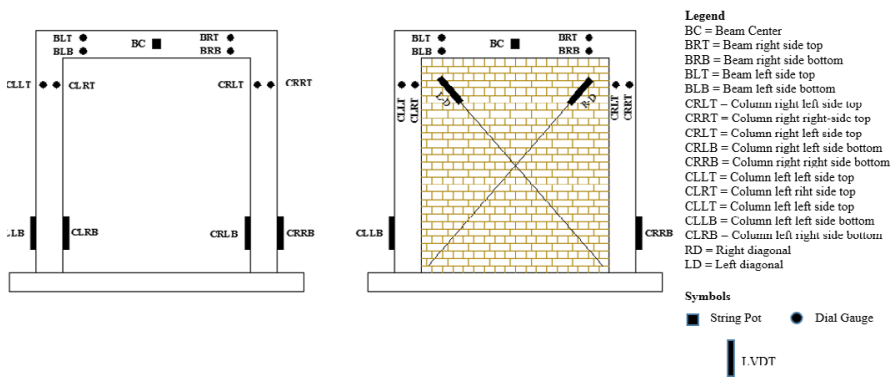

Figure 4: Schematic diagram for the instrumentation plan of Frames.

The test measurement setup includes two load cells of capacity $250 \mathrm{kN}$ (25 tons) and $500 \mathrm{kN}$ (50tons) to monitor vertical and horizontal induce loads, thirteen LVDTs, one string pot and four dial gauges as shown in Figure 4, details of instrumentations are given in Table 1.

The lateral loading protocol in-plane quasi-static loading was selected from FEMA 461 as shown in Figure 5, due to its gradually changing deformation amplitude.

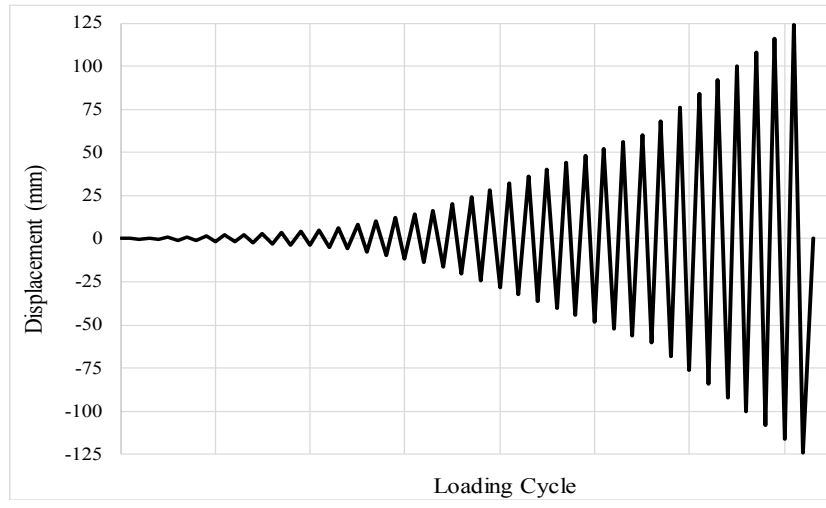

Figure 5: Loading protocol. 


\section{Results and Discussion}

Figures 6 and 7 exhibit hysteresis curves of Bare frame and Infilled frame respectively. Both the hysteretic loops were symmetrical in the forward and reverse direction of loading. With the increase of displacement, there was progressive increase in the lateral load. The response of load deformation was approximately linear up to $10 \mathrm{~mm}$ lateral displacement in either direction. After the initiation of cracking, the stiffness of both the frames decreased. At high load cycles, pinching in the hysteretic loops was observed. The lateral load-deformation (F-D) envelopes are also shown in Figure 8 for both the bare frame and infilled frame. Figure 8 shows an obvious difference between the initial stiffness and lateral load capacity of both frames. The RC frame without an infill wall has a peak strength of $51.87 \mathrm{kN}$ at a lateral deformation of $36.21 \mathrm{~mm}$. Comparing the maximum capacity of the bare frame with infilled frame, the maximum capacity of the infilled frame was $132.5 \mathrm{kN}$ at a displacement of $36.72 \mathrm{~mm}$. This assessment indicates that the RC frame with an infill wall has 2.5 times more stiffness than the RC frame without infill under to similar loading protocol. The maximum capacity of the infilled frame increases $175 \%$ as compared to an RC frame without an infill wall. Also, the lateral stiffness up to ultimate load for $\mathrm{RC}$ infilled frame increases $171 \%$ in comparison to bare $\mathrm{RC}$ frame.

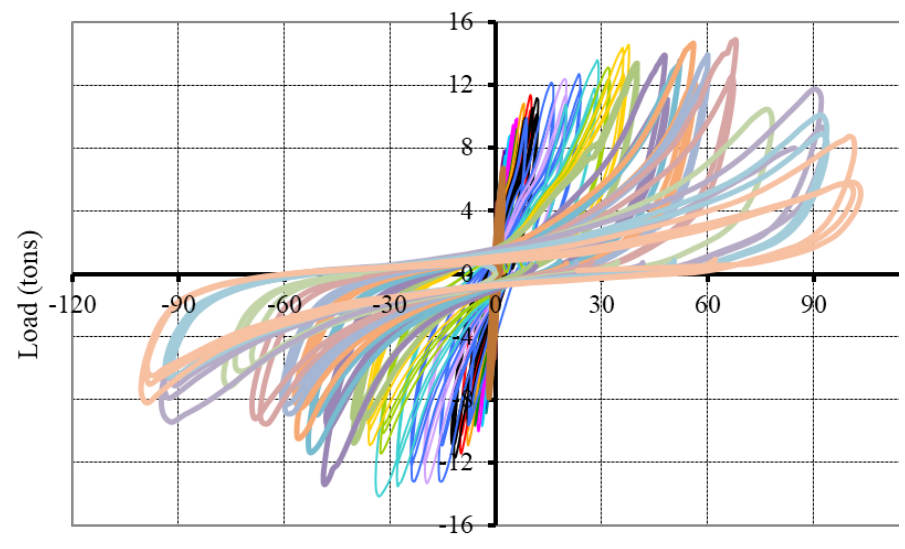

Figure 6: Hysteresis curves for Bare Frame.

\section{Numerical modeling}

The response of the structural components can be obtained by a non-linear finite element $(\mathrm{FE})$ analysis. The overall procedure for non-linear analysis has essentially three (03) fundamental parts: The finite element approach, the material model and the nonlinear solutions procedures, which essentially form a balanced estimate. However, the material models determine the behavior, and consequently discussed more widely here, whereas the finite element method and the nonlinear solution are stated briefly. Concerning research specialists in the area of applied mechanics and materials like Framcos, Fib, Rilem, it is known that the significant features to be incorporated in the concrete/brick model are tension stiffness and compression confinement (Negulescu, 2010). Numerous material models including these features are applied in the commercially available software Atena, which is a set of finite elements intended for the behavior analysis of structures.

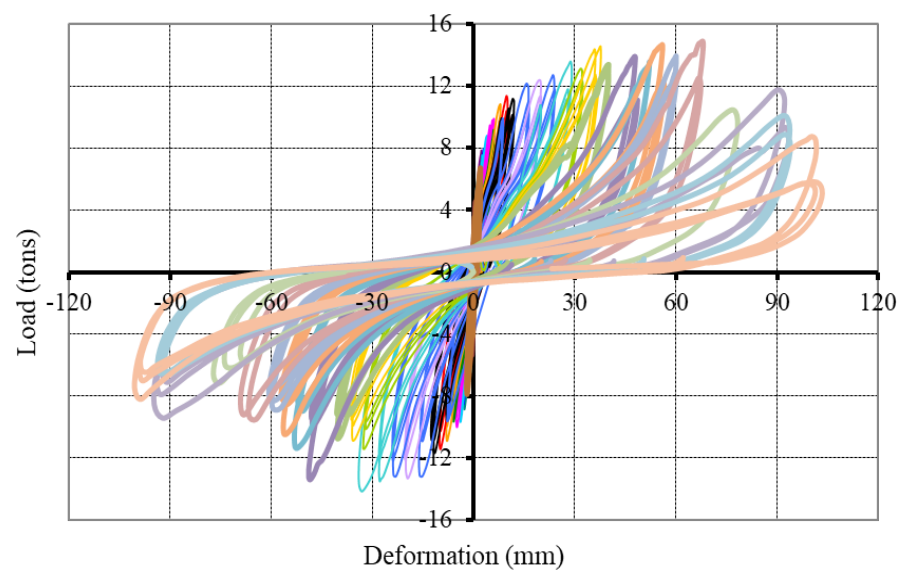

Figure 7: Hysteresis curve for Frame with Infill wall.

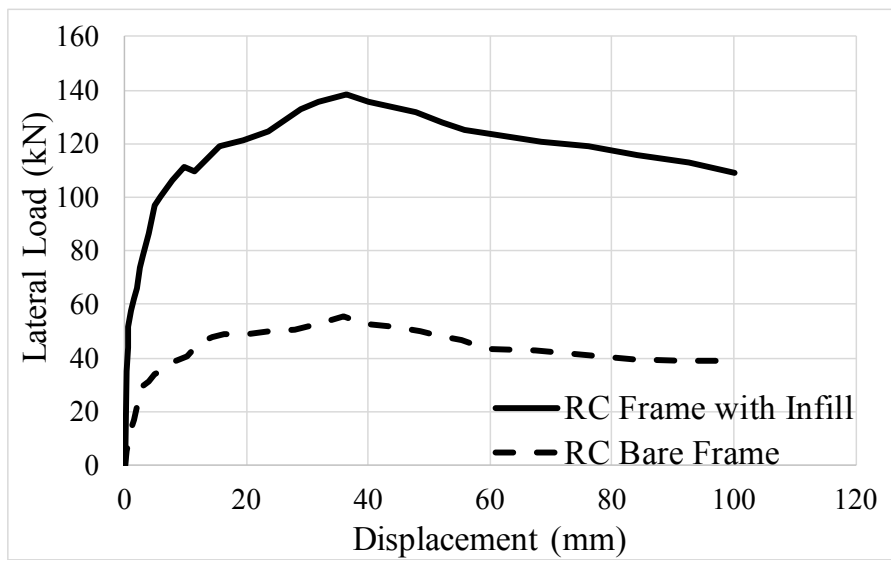

Figure 8: Envelop curves for bare frame and infill frame in the positive direction.

\section{Geometry and boundary conditions Modeling of RC frame}

To model the RC frame for both with and without infill walls, a material model named " $3 \mathrm{D}$ Non-linear cementitious-2" was used for concrete which is a Fracture-plastic model that joins the constitutive behaviors for tension (fracture) and compression (plastic) (Pukl et al., 2001). The tensile behavior depends on the conventional smeared crack function and cracks band behavior. It uses Rankine criteria of exponential softening and can be employed as a fixed 
or rotated crack approach. The plasticity model is the Menétrey-Willam failure approach. The model adopts a return mapping procedure for the combination of fracture and plasticity equations. The properties used for the model are given in Table 2. The compressive strength reduction factor is used as 0.8 which means that after tensile cracking the concrete compressive strength should not drop below $80 \%$ of the ultimate strength. Similarly, the fixed crack model coefficient is set to be 0.8 which means that after the initiation of cracks the crack will be allowed to rotate up to $20 \%$ reduction of the strength and after reaching the $80 \%$ of compressive strength the crack direction will get fixed. The reinforcement in the frame was modelled as discrete rebars with the same area of the bar and using the same no of bars as per experimental details. The material model used for rebars was "cyclic reinforcement". A bilinear model with hardening was used with a yield strength of $350 \mathrm{MPa}$.

Table 2: Properties of concrete for $R C$ frame.

\begin{tabular}{llll}
\hline Material Property & & Value & Units \\
\hline Elastic modulus & $\mathrm{E}_{\mathrm{c}}$ & 24.8 & $\mathrm{GPa}$ \\
Poisson's ratio & $\mathrm{v}$ & 0.2 & - \\
Compressive strength & $\mathrm{f}_{\mathrm{c}}$ & 20.6 & $\mathrm{MPa}$ \\
Tensile strength & $\mathrm{f}_{\mathrm{t}}$ & 1.23 & $\mathrm{MPa}$ \\
Fracture energy & $\mathrm{G}_{\mathrm{f}}$ & 57.93 & $\mathrm{~N} / \mathrm{m}$ \\
Tension Stiffening coefficient & $\mathrm{C}_{\mathrm{ts}}$ & 0.5 & - \\
Plastic strain at strength $\mathrm{fc}$ & $\varepsilon_{\mathrm{cp}}$ & $1.02 \times 10^{-3}$ & - \\
Critical compressive disp. & $\mathrm{w}_{\mathrm{d}}$ & $5 \times 10^{-4}$ & $\mathrm{~m}$ \\
Compressive strength reduction & $\mathrm{r}_{\mathrm{c}, \mathrm{lim}}$ & 0.8 & - \\
Fixed Crack model coefficient & & 0.8 & - \\
\hline
\end{tabular}

The bare frame model is shown in Figure 9. Where only the columns and beam are modelled along with the concrete pad. Since the beam was cast monolithically with the columns, also the columns were cast monolithically with the concrete pad, also the column reinforcement was continuous in the beam and bottom pad to build a mechanical bond, therefore a perfect connection was used between all these elements to avoid any relative displacement of the elements. To account for the reinforcement bond with surrounding concrete, the "perfect connection" option in Atena was opted, which applies full bond.

\section{Modeling of the infill panel}

To reasonably capture the damage pattern of the experimentally tested infilled frame, a simplified micro-modeling approach was adopted where the mortar joints are lumped into the brick units and the brick units were enlarged to keep the same structural geometry. This approach allows replicating the local failure mechanism of the tested structure with reasonable accuracy and less time requirements as compared to the detailed micro modeling approach. It is also worth mentioning that the macro-modeling approach has not opted here since it is effective in large structures and saves a lot of computational time but the local damage mechanism cannot be predicted by that approach, also it idealizes the masonry as a homogeneous material (Zucchini et al., 2009) which is not right because masonry is a heterogeneous material with the distinct unit and mortar properties, thus make a big limitation on adopting the macromodeling approach. A detailed description of all the three modeling methodologies has been presented in section 1 of this study. As already mentioned, the brick units were modeled connected by interface elements (representing the mortar joints and brick-mortar interface) therefore the material models were defined for both the elements and the properties obtained in the test program were adopted to verify the numerical models.

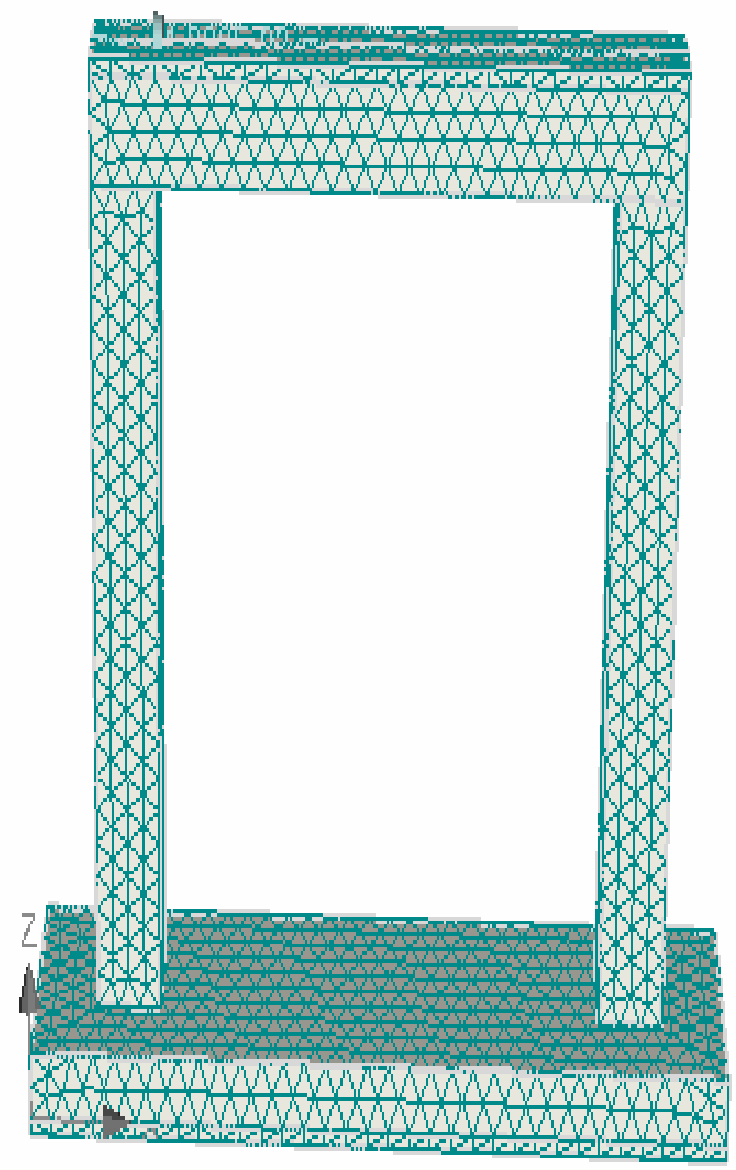

Figure 9: $R C$ frame model. 
Material models

Modeling the brick unit

The brick unit is modeled as a discrete element with distinct properties defined using 3D Nonlinear Cementitious-2 material (Pukl et al., 2001). The main material relations adopted for this model are presented in Figure 10. The behavior of the compressive uniaxial component has been described by a linear total stress curve (Figure 10) that starts at the beginning.

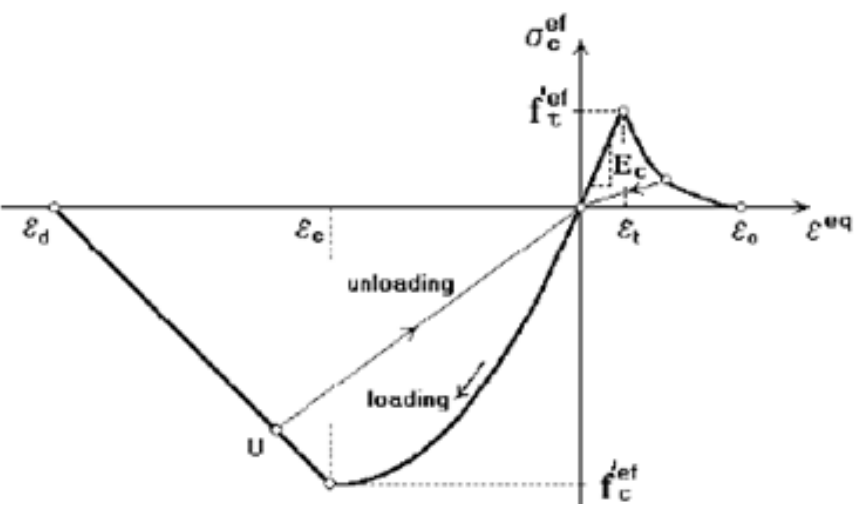

Figure 10: Material Model for Brick Element (Pukl et al., 2001).

The behavior of uniaxial tensile material was assumed linear elastic until failure with a constant elastic modulus equal to the slope of the first segment of the compression curve. Based on the laboratory tests carried out on the brick prisms, various properties were determined which were employed in the model description. The main characteristics of this model, namely elastic modulus, compressive strength, tensile strength, etc., were taken directly from the results obtained by laboratory tests of masonry prisms. The primary parameters used were determined experimentally and are summarized in Table 2.

An iso-parametric brick element was used to model the masonry unit. This solid element has six degrees of freedom (DOF) at each node: translations and rotations in the directions $\mathrm{x}, \mathrm{y}$ and $\mathrm{z}$. The shape of the rectangular element corresponds to the regular pattern of the masonry. The element has plasticity, tensile stress, large deviation, and large deformation proficiencies, see Figure 11.

\section{Modeling the mortar joints}

Since the properties of mortar generally dominate the response of masonry (Zucchini and Lourenco, 2009), thus appropriate modeling of these joints is critical. "No separation" contact model was adopted in the analysis given its ability to simulate the behavior of joints with reasonable accuracy. This contact model allows not only the sliding between the contact surfaces but also allows the contact to be opened by adjusting the contact opening stiffness (Figures 12, 13).

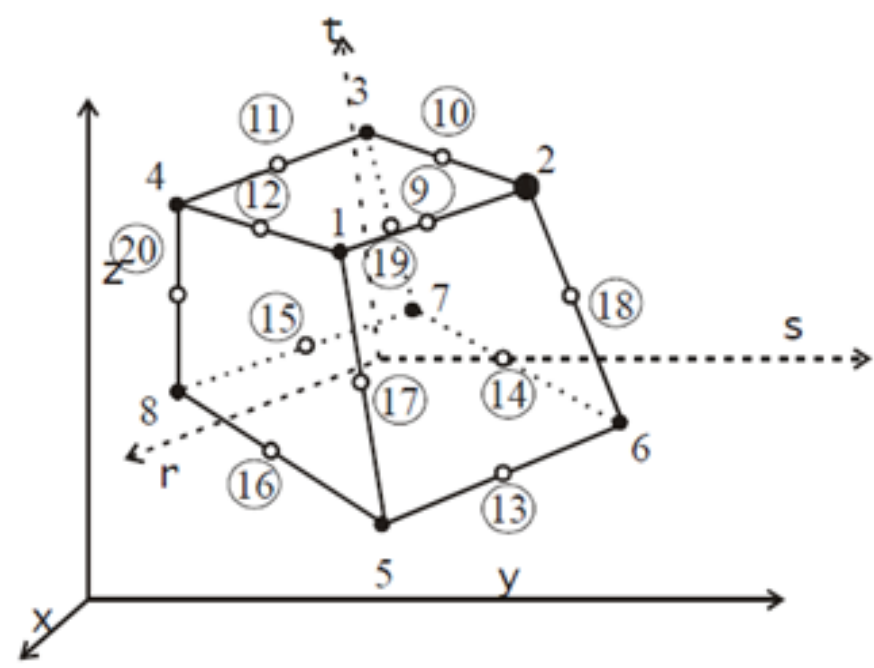

Figure 11: Geometry details of Isoparametric brick element (Pukl et al., 2001).

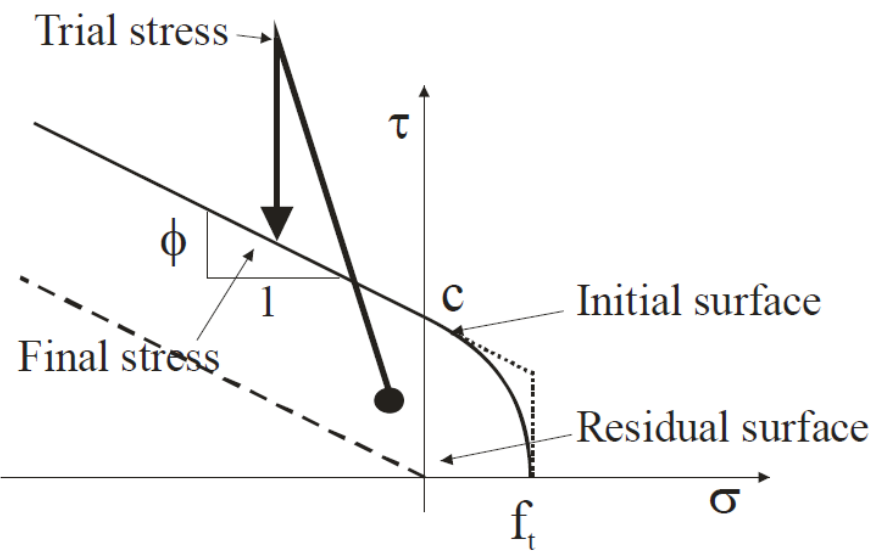

Figure 12: Failure surface for Interface element (Pukl et al., 2001).
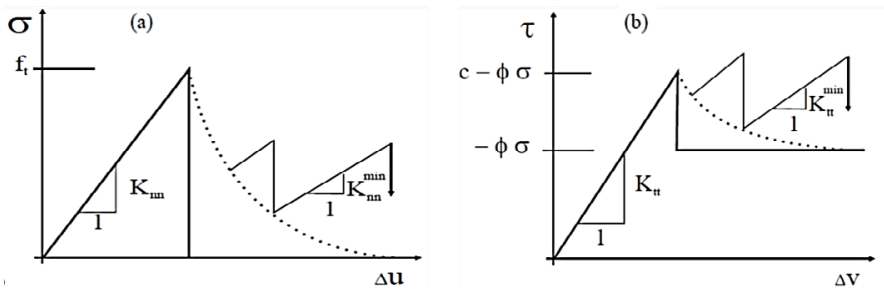

Figure 13: Typical interface model behavior in (a) shear and (b) tension (Pukl et al., 2001).

The joints represent the connections between the microelements. The Mohr-Coulomb connection has been employed to signify the joints. The primary parameters used for the interface element were determined experimentally and are given in Table 3. 
Table 3: Summary of material properties.

\begin{tabular}{llllllllllll}
\hline Topology & \multicolumn{4}{c}{ Contact - Joint } & \multicolumn{4}{c}{ Brick - Element } \\
\hline Material & \multicolumn{4}{c}{ 3D Interface } & \multicolumn{4}{c}{ 3D Non-Linear Cementitious2 } \\
\hline Parameters & $\mathrm{Knn}$ & $\mathrm{Ktt}$ & $\mathrm{Ft}$ & $\mathrm{c}$ & $\Phi$ & $\mathrm{E}$ & $\mathrm{G}_{\mathrm{F}}$ & $\mathrm{v}$ & $\mathrm{ft}$ & $\mathrm{fc}$ \\
& $\mathrm{MN} / \mathrm{m}^{3}$ & $\mathrm{MN} / \mathrm{m}^{3}$ & $\mathrm{MPa}$ & $\mathrm{MPa}$ & & $\mathrm{GPa}$ & $\mathrm{N} / \mathrm{m}$ & & $\mathrm{MPa}$ & $\mathrm{MPa}$ \\
Values & 85000 & 56500 & 0.12 & 0.08 & 0.65 & 14.34 & & 36.49 & 0.2 & 0.46 & 8.75 \\
\hline
\end{tabular}

The same interface element was used for connecting brick units with the adjacent $\mathrm{RC}$ frame.

\section{Meshing, loading and solution parameters}

A 3D micro modeling of masonry with geometric characteristics equal to those confirmed in the laboratory (Figure 14) was adopted using FE software (Atena 3D) that had employed the material model adopted. The iterative method of Newton-Raphson was employed to solve the numerical equations. The loading was simulated by imposing a constant vertical load and a monotonic lateral displacement. The assessment of monotonic and cyclic testing consequences proposes that the loading protocol is not significant if one is concerned about the load capacity of the structure. Since the main purpose of the numerical modeling was to perform the parametric analysis of the experimentally tested frames to understand the behavior regarding its lateral load response. Thus, the assumption was considered valid and only monotonic loading was applied while calibrating the model and also in the parametric analysis. The displacements were imposed in small steps (displacement of $1 \mathrm{~mm}$ per step), with linear variation and uniform growth.

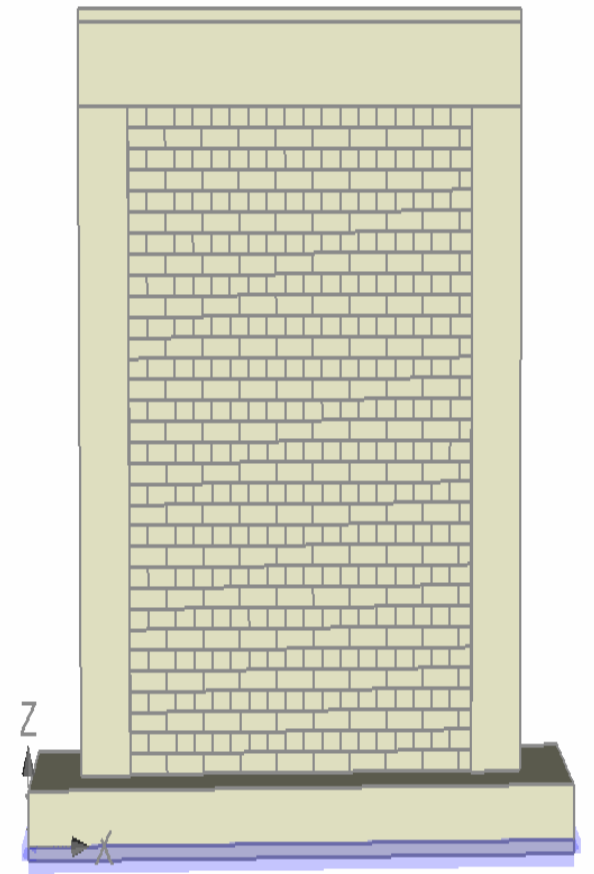

Figure 14: Simplified micro modeling approach.

\section{Comparison of experimental vs numerical results}

The backbone curve was drawn from the Hysteresis curves (Figures 6 and 7) and compared to the results obtained from numerical modeling values. Figure 15 shows the comparative results of the bare frame for both the experimental testing as well as numerical modelling. The numerical results obtained show good relation with the experimental results.

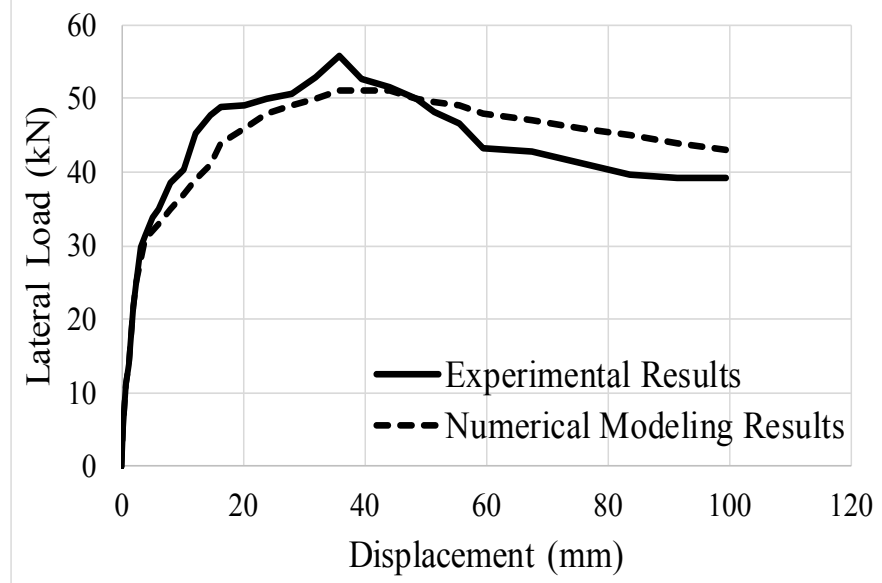

Figure 15: Results comparison of bare frame.

Figure 16 shows the comparative results obtained for RC frame with infill wall from experimental testing and numerical modelling. The initial stiffness of numerical curve matches with experimental one up to a load value of $40 \mathrm{kN}$ however, after that the numerical model shoes a relatively less stiff behavior. Similarly, the maximum lateral load for numerical model occurs at a displacement of $18 \mathrm{~mm}$, while that of experimental one occurs at $37 \mathrm{~mm}$. The lateral load resistance of numerical model starts decreasing after $20 \mathrm{~mm}$ but on the other hand, it increases up to 38 $\mathrm{mm}$ for the experimental model and starts reducing after that. Also, the post peak (softening) path of both the curves differ up to some extent, with the fact that numerical model stops at a displacement of 88 $\mathrm{mm}$ and lateral load of $84 \mathrm{kN}$ while the experimental model reaches $100 \mathrm{~mm}$ displacement with lateral load of $110 \mathrm{kN}$. It is seen that the proposed model can detect the key aspects of the tested behavior of the walls. The damage mechanism and load-deformation diagrams are partially well replicated. 


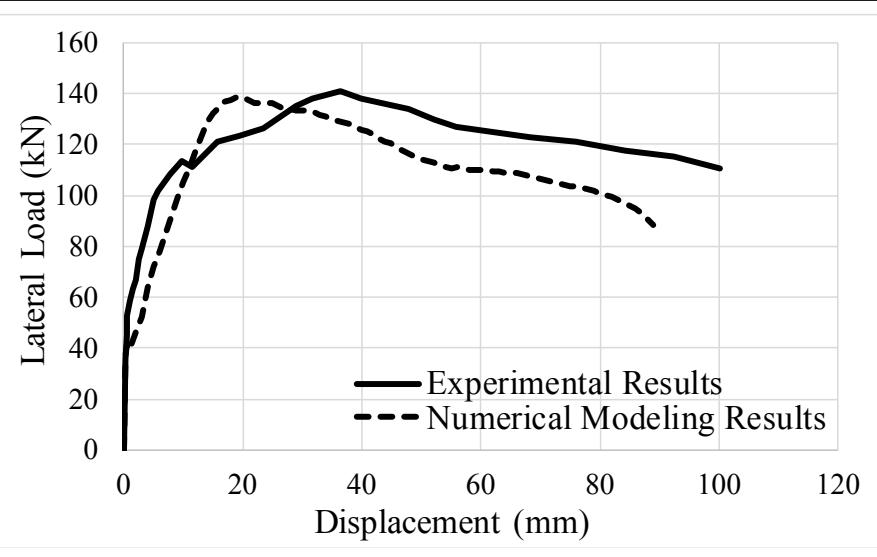

Figure 16: Results comparison of infilled frame.

Figure 17 shows the comparison of the damage pattern of the infilled frame by experimentally testing and numerical modelling. The damage pattern follows the actual damage pattern of the system very much. However, the crack formation in the panel indicates the same damage pattern and predicts the same stress concentration point as obtained from lab tests as well as the micro-modeling approach.
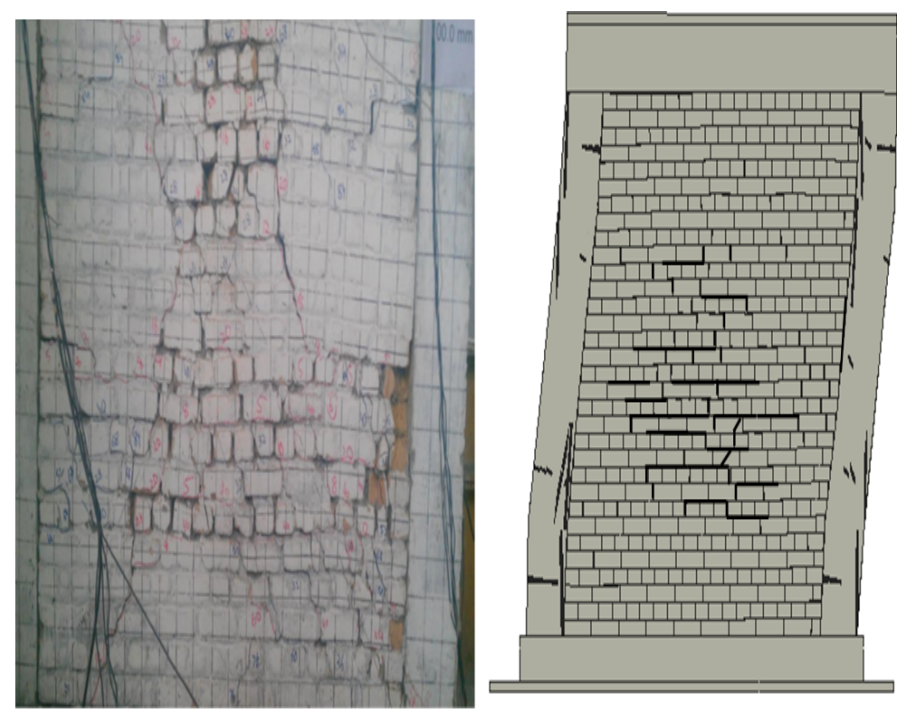

Figure 17: Comparison of damage pattern of infill wall.

The main purpose of this study was to determine the effect of infilled brick wall on the lateral load performance of the RC structure. As presented previously in detail, the inclusion of infilled wall not only stiffens the RC frame (about 171\%) but it also increases its lateral load performance considerably (i.e., 175\%). The models were then generated in FEA based software with the material properties and boundary conditions similar to the experimentally tested frames. The numerical model seemed to replicated the actual tested frames with marginal but acceptable accuracy of predicting the maximum lateral load as well as the damage pattern of both bare frame as well as infilled frame. After the agreement of the results of experimental and numerical models, a parametric study was performed to check the effect of different parameters by keeping the boundary conditions and frame dimensions similar to the originally tested frame.

\section{Parametric study}

\section{Numerical model of the parametric study}

In parametric study, the properties used for steel and concrete as well as the geometry of the assembly were kept the same, since the main objective was to evaluate the influence of masonry infill wall on the response of $\mathrm{RC}$ frame structure. Therefore, the material properties of brick units were changed to see their effect on the behavior of the structure.

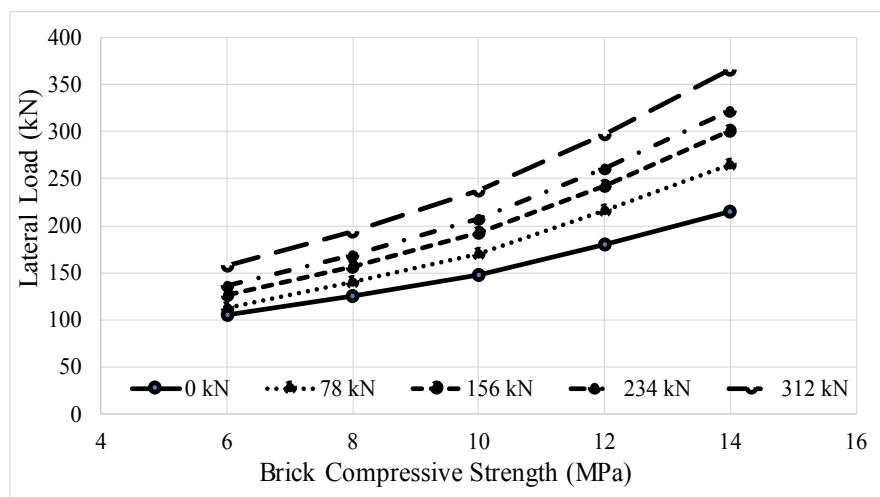

Figure 18: Effect of gravity load and brick compressive strength on the lateral load response of the $R C$ infilled frame.

\section{Parameters under consideration}

To study the effect of brick properties on the response of infilled $\mathrm{RC}$ frame by varying the brick strength of 4, 6, 8, 10 and $12 \mathrm{MPa}$. All the five types of frames were subjected to five different types of gravity load levels i.e. $0 \mathrm{kN}, 78 \mathrm{kN}, 156 \mathrm{kN}, 234 \mathrm{kN}$ and $312 \mathrm{kN}$. Thus, making a total of twenty-five (25) studies to be performed and the lateral load capacity (i.e. maximum lateral load of the frame) was calculated. Results are presented in Figure 18, where it is seen that increasing the brick strength from $4 \mathrm{MPa}$ to $12 \mathrm{MPa}$, increases the maximum capacity of the infilled frame from 115 $\mathrm{kN}$ to $205 \mathrm{kN}$, in the absence of any gravity load. Similarly, for the gravity load of $312 \mathrm{kN}$, the effect of brick compressive strength is more obvious on the response of the structure, thus increasing it from 160 $\mathrm{kN}$ for $4 \mathrm{MPa}$ brick strength to $360 \mathrm{kN}$ for $12 \mathrm{MPa}$ of brick compressive strength. Thus, it can be stated that for the same masonry properties, the maximum capacity of the infilled frame increases by increasing 
the gravity load on the structure. Similarly, under the same gravity load level, the capacity of the infilled frame enhances by enhancing the properties of the masonry (in this case only brick unit properties are considered and mortar properties are kept constant).

\section{Conclusions and Recommendations}

This paper presents both the experimental and numerical study of the influence of Masonry infill on the behavior of $\mathrm{RC}$ frames. In experimental work, the quantitative comparison was made between both types of frames (with and without infill panel) based on initial stiffness, ultimate strength and ultimate displacement. The same structures were then modelled numerically in an FEA software Atena, using a simplified micro modeling approach. The model predicts the non-linear response of infilled frame by capturing all potential modes of failure. Appropriate material models and biaxial damage criteria were chosen, and masonry is supposed to be an anisotropic material. The shear and bending distortions, which play a significant role in the overall behavior of the walls, have been taken into account. The presented computing method can be used to predict the response of infilled frames with diverse material and geometric properties. The peak lateral load determined by numerical model gives $90 \%$ and $98 \%$ of the maximum lateral load obtained from experimental testing for bare frame and infilled frame, respectively.

The precision of the method accepted is obtained by comparison of experimental and numerical results. It is presented that the precision of the prophesied results is satisfactory. After calibrating the numerical model, a parametric analysis was led in which the brick unit properties were changed, subjected to different gravity load levels. It was demonstrated that for the same gravity load level the enhancement of brick unit properties enhances the total capacity of the RC frame with infill. Similarly, by increasing the gravity load on the structure with the same brick unit properties, the lateral load capacity increases considerably. It should be noted that current study is based on single bare frame and single infilled frame tests and hence the scope is very limited and cannot be taken as a representative for all kind of infilled structures.

\section{Novelty Statement}

The key influence of this work is to study the lateral load behavior of RC frame elements with and without masonry infill and to demonstrate the use of computer simulations to predict masonry behavior (i.e., to conduct the parametric study with different mechanical properties).

\section{Author's Contribution}

Syed Azmat Ali Shah: Experimental testing and analysis.

Asfandyar Ahmed: Numerical analysis

Khan Shahzada: Contributed to the design and implementation of the research.

Syed Muhammad Ali: Conceived and planned the experiments

Akhtar Naeem Khan Main: Conceptual ideas and proof outline

Akhter Gul: Involved in planning and supervised the fabrication of the specimen.

\section{Conflict of interest}

The authors have declared no conflict of interest.

\section{References}

Andreaus, U. and A. di Paolo. 1988a. A 3d finite element model for the analysis of masonry structures. In: Proceedings of the 8th international brick and block masonry conference, Dublin, 3P: 1405-1416.

Andreaus, U. and A. di Paolo. 1988b. 3d analysis of masonry columns with grouted reinforcement bars. In: Proceedings of the $8^{\text {th }}$ international brick and block masonry conference, Dublin; 3: 1507-1518.

Andreaus, U. and G. Ceradini. 1992. Failure modes of solid brick masonry under in-plane loading. Masonry Int. 6(1): 4-8.

Andreaus, U. and L. Ippoliti. 1995a. A two story masonry wall under cyclic loading: A comparison between experimental and numerical results. In: Proceedings of the $3^{\text {rd }}$ international symposium on computer methods in structural masonry, Lisbon, 1: 68-77.

Andreaus, U. and L. Ippoliti. 1995b. Masonry panel under in-plane loading: A comparison between experimental and numerical results. In: Proceedings of the $3^{\text {rd }}$ international symposium 
on computational methods and experimental measurements, Capri, Italy; 1: 603-610.

Andreaus, U. and L. Ippoliti. 1995c. A two story masonry wall under monotonic loading: A comparison between experimental and numerical results. In: Proceedings of the $4^{\text {th }}$ international conference on structural repair and maintenance of historical buildings, Creta, 1: 319-326.

Andreaus, U., 1996. Failure criteria for masonry panels under in-plane loading. J. Struct. Eng., 122(1): 37-46. https://doi.org/10.1061/ (ASCE)0733-9445(1996)122:1(37)

Andreaus, U., G. Ceradini, M. Cerone and P. D’Asdia. 1985a. Masonry columns under horizontal loads: A comparison between finite element modeling and experimental results. In: Proceedings of the 7th international brick and block masonry conference, Melbourne, pp. 469-478.

Andreaus, U., M. Cerone, P. D'Asdia and F. Lannozzi. 1985b. A finite element model for the analysis of masonry structures under cyclic actions. In: Proceedings of the $7^{\text {th }}$ international brick and block masonry conference,Melbourne, 1: 479-488.

Asteris, P.G. and A.D. Tzamtzis. 2003a. Nonlinear seismic response analysis of realistic gravity dam-reservoir systems. Int. J. Nonlin. Sci. Num. Simul., 4(4): 329-338. https://doi.org/10.1515/ IJNSNS.2003.4.4.329

Asteris, P.G. and A.D. Tzamtzis. 2003b. On the use of a regular yield surface for the analysis of unreinforced masonry walls. Electron. J. Struct. Eng., 3: 23-42.

Balan, T.A., E. Spacone and M. Kown. 2000. A 3D hypoplastic model for cyclic analysis of concrete structures. Eng. Struct., 23: 333-342. https:// doi.org/10.1016/S0141-0296(00)00048-1

Balan, T.A., F.C. Filippou and E.P. Popov. 1997. Constitutive model for 3D cyclic analysis of concrete structures. J. Eng. Mech. Div. ASCE, 123: 143-153. https://doi.org/10.1061/ (ASCE)0733-9399(1997)123:2(143)

Barpi, F., 2004. Impact behaviour of concrete: A computational approach. Eng. Fract. Mech., 71(2): 197-213.

Bertero, V. and S. Brokken. 1983. Infills in seismic resistant building. ASCE J. Struct. Eng., 109(6): 1337-1361. https://doi.org/10.1061/ (ASCE)0733-9445(1983)109:6(1337)
Building Code of Pakistan, Seismic Provision, SP-2007. Ministry of Housing and works, Government of Islamic republic of Pakistan, 2007.

Buyukozturk, O. and S.S. Sareef. 1985. Constitutive modeling of concrete in finite element analysis. Comput. Struct., 21: 581-610. https://doi. org/10.1016/0045-7949(85)90135-X

Cela, J.J.L., 1998. Analysis of reinforced concrete structures subjected to dynamic loads with a visco plastic Drucker, Prager model. Appl. Math. Model, 22: 495-515. https://doi.org/10.1016/ S0307-904X(98)10050-1

Cervenka, V., J. Cervenka and R.P. Atena. 2002. A tool for engineering analysis of fracture in concrete, Sadhana 27(4): 485-492. https://doi. org/10.1007/BF02706996

Cervera, M., J. Oliver, O. Manzoli. 1996. A ratedependentisotropicdamagemodelfortheseismic analysis of concrete dams. Earthq. Eng. Struct. Dyn., 25: 987-1010. https://doi.org/10.1002/ (SICI)1096-9845(199609)25:9<987::AIDEQE599>3.0.CO;2-X

Chang-Hai,Z., 2014. Experimental investigation of in-plane seismic behavior of full-scale masonry infilled RC frames. Int. Works. Seismic Perf. Non-Struct. Elem. (SPONSE), August 29-31, 2014.

Chen, A.C.T. and W.F. Chen. 1975. Constitutive relations for concrete. J. Eng. Mech. Div. ASCE, 101: 465-481. https://doi.org/10.1061/ JMCEA3.0002034

Chen, E.S. and O. Buyukozturk. 1985. Constitutive model for concrete in cyclic compression. J. Eng. Mech. Div. ASCE, 111: 797-815. https://doi.org/10.1061/(ASCE)07339399(1985)111:6(797)

Dube, J-F., G. Pijaudier-Cabot and C. La Borderie. 1996. Rate dependent damage model for concrete in dynamics. J. Eng. Mech. Div. ASCE, 122: 359-380. https://doi.org/10.1061/ (ASCE)0733-9399(1996)122:10(939)

Fardis, M.N., B. Alibe and J.L. Tassoulas. 1983. Monotonic and cyclic constitutive law for concrete. J. Eng. Mech. Div. ASCE, 109: 516536. https://doi.org/10.1061/(ASCE)07339399(1983)109:2(516)

Faria, R., J. Olivera and M. Cevera. 1998. A strainbased plastic viscous-damage model for massive concrete structures. Int. J. Solids Struct., 35: 1533-1558. https://doi.org/10.1016/S0020- 
7683(97)00119-4

Federal Emergency Management Agency (FEMA). 2000. Prestandard and commentary for the seismic rehabilitation of buildings. Report no. FEMA 356, FEMA, Washington, DC; 2000.

Federal Emergency Management Agency. 2007. FEMA 461. Interim protocols for determining seismic performance characteristics of structural and non-structural components through laboratory testing. Redwood City, CA.

Fiore, A., F. Porco, G. Uva and M. Sangirardi. 2014. The influence of uncertainties of infill panels relative to the seismic response of $\mathrm{RC}$ existing buildings. Structures Under Shock and Impact XIII. https://doi.org/10.2495/SUSI140411

Gomes, H.M. and A.M. Awruch. 2001. Some aspects on three-dimensional numerical modelling of reinforced concrete structures using the finite element method. Adv. Eng. Softw., 32: 257-277. https://doi.org/10.1016/ S0965-9978(00)00093-4

Grassl, P., K. Lundgren and K. Gylltoft. 2001. Concrete in compression: A plasticity theory with a novel hardening law. Int. J. Solids Struct., 39: 5205-5223. https://doi.org/10.1016/ S0020-7683(02)00408-0

Hashemi, A. and K.M. Mosalam. 2006. Shaketable experiment on reinforced concrete structure containing masonry in fill wall. J. Eq. Eng. Struct. Dyn., 9(1): 73-83.

Hatzigeorgiou, G., D. Beskos, D. Theodorakopoulos and M. Sfakianakis. 2001. A simple concrete damage model for dynamic FEM applications. Int. J. Comput. Eng. Sci., 2: 267-286. https:// doi.org/10.1142/S1465876301000325

Kang, H.D., K. William, B. Shing and E. Spacone. 2000. Failure analysis of RC columns using a triaxial concrete model. Comput. Struct.,77: 423-440. $\quad$ https://doi.org/10.1016/S00457949(00)00006-7

Kauffman,A. and A.M.Memari.2014.Performance evaluation of different masonry infill walls with structural fuse elements based on in-plane cyclic load testing. Buildings, 4: 605-634. https://doi. org/10.3390/buildings4040605

Korkmaz, S.Z., Kamanli M., Korkmaz H.H., Donduren M.S., and Cogurcu M.T. 2010. Experimental study on the behaviour of nonductile infilled $\mathrm{RC}$ frames strengthened with external mesh reinforcement and plaster composite. Nat. Hazard. Earth Syst. Sci.,
10: 2305-2316. https://doi.org/10.5194/ nhess-10-2305-2010

Koutromanos, Stavridis A., Shing B.P., and Willam, K. 2011. Numerical modeling of masonryinfilled RC frames subjected to seismic loads. Comp. Struct., 89(2011): 1026-1037. https:// doi.org/10.1016/j.compstruc.2011.01.006

Kyriakides, M.A. and S.L. Billington. 2008. Seismic retrofit of masonry-infilled nonductile reinforced concrete frames using sprayable ductile fiber-reinforced cementitious composites. Proc. 14 ${ }^{\text {th }}$ World Conf. Earthq. Eng., October 12-17, 2008, Beijing, China.

Liu, T.C.Y., 1971. Stress-strain response and fracture of concrete in biaxial compression. Research report no. 339. Dept. of Structural Engg. Cornell University,

Liu, T.C.Y., A.H. Nilson and F.O. Slate. 1972. Biaxial stress-strain relations for concrete. ACI Struct. J., 98: 1025-1034. https://doi. org/10.1061/JSDEAG.0003222

Lourenco, P., 2002. Computations on historic masonry structures. Prog. Struct. Eng. Mater., 4(3): 301-319. https://doi.org/10.1002/pse.120

Mehrabi, A.B., P.B. Shing, M.B. Schuller and J.L. Noland. 1994. Performance of masonry-infilled $\mathrm{R} / \mathrm{C}$ frames under in-plane lateral loads. Report CU/SR-94/6, Department of Civil.

Negulescu, C., 2010. Evaluarea vulnerabilității fondului construit înainte de 1977 în Bucuresti, în funcție de condițiile locale de teren. $\mathrm{Ph}$. $\mathrm{D}$. Diss., Technical Univ. of Constr., Bucharest, 2010.

Page, A., 1978. Finite element model for masonry. J. Struct. Div., 104(8): 1267-1285. https://doi. org/10.1061/JSDEAG.0004969

Pauw, A., 1960. Static modulus of elasticity of concrete as affected by density. ACI J., 57: 679688. https://doi.org/10.14359/8040

Polyakov, S.V., 1960. On the interaction between masonry infill walls and enclosing frame when loaded in the plane of the wall. Earthq. Eng., EERI, San Francisco, pp. 36-42.

Popovics, S., 1973. A numerical approach to the complete stress-strain curve of concrete. Cement Conc. Res., 3: 816-825. https://doi. org/10.1016/0008-8846(73)90096-3

Pukl, R., J. Cervenka and V. Cervenka. 2001. Simulating a response of connections. Proc. RILEM Symp. On Connections between Steel and Concrete, Stuttgart, Germany. 
Rosenblueth, E. and R. Meli. 1986. The 1985 Mexico earthquake: Causes and effects in Mexico City. Conc. Int., pp. 23-34.

Shing B.P., Stavridis A., Koutromanos I., Willam K., Blackard B., Kyriakides A.M., Billington L.S., and Arnold S. 2009. Seismic performance of non-ductile RC frames with brick infill. Proceedings of ATC and SEI 2009 conference on improving the seismic performance of existing buildings and other structures. https:// doi.org/10.1061/41084(364)102

Stavridis, A. and P.B. Shing. 2010. Finite element modeling of nonlinear behavior of masonryinfilled RC frames. J. Struct. Eng., 136(3): 285296. https://doi.org/10.1061/(ASCE)ST.1943541X.116

Tasnimi, A.A. and A. Mohebkhah. 2011. Investigation on the behavior of brick-infilled steel frames with openings, experimental and analytical approaches. Eng. Struct., 33(3): 968-980. https://doi.org/10.1016/j. engstruct.2010.12.018

Thabet, A, and D. Haldane. 2001. Threedimensional numerical simulation of the behaviour of standard concrete test specimens when subjected to impact loading. Comp. Struct., 79: 21-31. https://doi.org/10.1016/ S0045-7949(00)00109-7

Yang, B-L., Y.F. Dafalias and L.R. Herrmann. 1985. A bounding surface plasticity model for concrete. J. Eng. Mech. Div. ASCE, 111: 359380. https://doi.org/10.1061/(ASCE)07339399(1985)111:3(359)

Zucchini, A. and P.B. Lourenco. 2009. Validation of a micro-mechanical homogenization model: Application to shear walls. Int. J. Solids Struct., 46(3-4): 871-886. https://doi.org/10.1016/j. ijsolstr.2008.09.034 